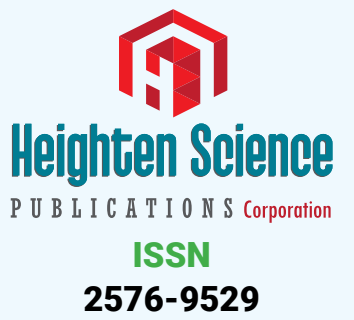

*Address for Correspondence: Shahrzad Ossareh, MD, Professor of Medicine, Head, Hemodialysis Ward, Hasheminejad Kidney Center, Iran University of Medical Sciences, Director of Nephrology Fellowship Program, Hasheminejad Kidney Center, Iran University of Medical Sciences, Iran, Tel: 0098-21-8864 4420, Fax: 0098-21-8864 4441; Email: ossareh_s@hotmail.com

Submitted: 18 October 2018

Approved: 05 January 2019

Published: 07 January 2019

Copyright: @ 2019 Ossareh S, et al. This is an open access article distributed under the Creative Commons Attribution License, which permits unrestricted use, distribution, and reproduction in any medium, provided the original work is properly cited

Keywords: Cardiovascular calcification; Valvular calcification; Vascular calcification; Fetuin A; Hemodialysis

Check for updates
Research Article

\section{Relationship between Fetuin-A and vascular or valvular calcification in hemodialysis patients}

\author{
Shahrzad Ossareh ${ }^{1 *}$, Bahareh Marghoob and Robabeh Bayat ${ }^{2}$ \\ 'Department of Medicine, Nephrology Section, Hasheminejad Kidney center, Iran University of \\ Medical Sciences, Tehran, Iran \\ ${ }^{2}$ Department of Cardioligy, Moheb Mehr Hospital, Tehran, Iran
}

\section{Abstract}

Purpose: Deficiency of Fetuin A, as a calcification inhibitor, is assumed to be involved in vascular calcification in patients on maintenance hemodialysis (MHD). This study examined the relationship between serum Fetuin-A and vascular and valvular calcification in a cohort of MHD patients.

Methods: The study was conducted on 122 MHD patients. Serum levels of calcium, phosphorus, parathormone, and Fetuin-A were tested. Intima-media thickness (IMT) $\geq 0.8 \mathrm{~mm}$ and the presence of stenosis $>50 \%$ or plaques in carotid doppler sonography were considered as vascular calcification. Calcification of cardiac valves or mitral annular calcification in twodimensional echocardiography, were considered as cardiac valvular calcification. The presence of any or both of the two conditions was defined as cardiovascular calcification (CVC).

Results: Fetuin-A was lower than normal in $37 \%$ of 122 . Totally 106 patients (87\%) had CVC, who were older $(61 \pm 14$ vs. $38 \pm 14$ years, $P<0.001)$, more affected by diabetes $(54 \%$ vs. $13 \%$, $P=0.007$ ), had a longer dialysis vintage (median 5 vs. 2 years, $P=0.006$ ), lower levels of creatinine $(8.9 \pm 2.8$ vs. $11.9 \pm 3.1 \mathrm{mg} / \mathrm{dL}, P<0.001)$ and higher levels of calcium $(8.7 \pm 0.7$ vs. $8.4 \pm 0.5 \mathrm{mg} / \mathrm{dL}$, $P=0.026)$. There was no significant difference in mean Fetuin- $A$ level between the two groups $(P=0.101)$. In logistic regression increased age $(O R=1.1, C l 95 \%=1.1-1.2)$ and serum calcium $(\mathrm{OR}=2.8, \mathrm{Cl} 95 \%=1.1-7.6)$, and diabetes mellitus $(\mathrm{OR}=7.4, \mathrm{Cl} 95 \%=1.1-47.4)$ were risk factors.

Conclusion: This study showed that $87 \%$ of our patients had vascular and/or valvular calcification. Increased age and calcium level and diabetes were the predictors of CVC, whereas Fetuin-A was not.

\title{
Introduction
}

Cardiovascular diseases account for $50 \%$ of mortality in patients with end-stage kidney disease (ESKD) [1]. The prevalence of these diseases among hemodialysis patients is about 10-30 times higher than that among general population of the same age and sex [2]. The high prevalence of cardiovascular events in ESKD patients is associated with traditional risk factors including hypertension, dyslipidemia, diabetes mellitus, and smoking. However, all cases of mortality in these patients are not explained by these factors, suggesting the presence of some other risk factors such as cardiovascular calcification (CVC) $[3,4]$.

Vascular and valvular calcifications are the most common forms of extra-osseous calcification in ESKD patients [2]. CVC is associated not only with the traditional risk factors, but also with factors such as abnormalities in the levels of calcium, phosphorus, $\mathrm{PTH}$, and vitamin D [5]. Therefore, because of the high prevalence of such risk factors in ESKD patients, they are more vulnerable to the risk of CVC [6]. According to a study in dialysis patients, coronary artery calcification is about $2.5-5$ times more prevalent than

How to cite this article: Ossareh S, Marghoob B, Bayat R. Relationship between Fetuin-A and vascular or valvular calcification in hemodialysis patients. J Clini Nephrol. 2019; 3: 001-011. https://doi.org/10.29328/journal.jcn.1001021 
that in non-dialysis patients. In addition, the prevalence of cardiac valvular calcification in dialysis patients is more than $50 \%$ [7]. It has been shown that vascular calcification is an independent predictor of morbidity and mortality in ESKD patients [8].

Vascular calcification is not only caused by passive precipitation of calciumphosphate in vascular wall but is also due to an active process caused by induction of the expression of bone-associated genes in vascular smooh muscle cells (VSMC) $[9,10]$. A number of calcification inhibitors such as Fetuin-A, Matrix Gla protein (MGP) and Osteoprotegerin (OPG) are able to prevent soft tissue calcification [10].

Vascular calcification may happen in two main types of intimal calcification, as a part of diffuse atherosclerosis, and medial calcification, which is generally focal in distribution, unrelated to atherosclerotic risk factors, and seen in younger hemodialysis patients. Pathogenesis may be genetic, mineral metabolism- related, or non-mineral metabolism related [10].

Fetuin-A or a2-Heremans-Schmid glycoprotein is produced in the liver and acts as a strong inhibitor of calcium - phosphate deposition [10]. Fetuin-A can regulate several of the key cellular events that lead to VSMC calcification, including apoptosis, vesicle calcification, and phagocytosis [11]. It interacts directly with matrix vesicle release and also forms stable colloidal spheres with calcium and phosphorus, so-called "calciprotein particles" which inhibit hydroxyapatite precipitation and hence may modulate vascular calcification processes locally and at early stages [10] In patients on maintenance hemodialysis (MHD) the level of Fetuin-A is lower than that in healthy population and various studies have found an association between low levels of Fetuin- $\mathrm{A}$ and coronary artery calcification, the presence of carotid plaques, valvular calcification, and mortality in ESKD patients [12-15]. However, some studies have failed to find a direct relationship between the reduction in serum level of Fetuin-A and calcification in chronic kidney disease (CKD) or hemodialysis patients [16-18]. It has also been reported that Fetuin-A level is inversely associated with increased risk of cardiovascular mortality in hemodialysis patients [19]. However, this has not been proved in a number of other studies [18-20]. Thus, apparently further studies are required to investigate the complex relationship between Fetuin-A level and CVC in dialysis patients.

The majority of previous studies investigating the role of Fetuin-A in CVC have been focused on coronary artery calcification and few studies have investigated the relationship between Fetuin-A and valvular calcification and carotid intima media thickness (IMT) [21-23]. Also, the results of such studies have been controversial. Accordingly, the aim of this study was to examine the relationship between Fetuin-A levels of a cohort of MHD patients with cardiac valvular and vascular calcification.

\section{Materials and Methods}

This cross-sectional study was conducted in hemodialysis ward of Hasheminejad kidney Center in Tehran in 2013. Inclusion criteria were being over 18 years old and undergoing MHD for at least 3 months. Exclusion criteria were a recent history of trauma, acute coronary syndrome, acute infection, and acute hepatitis which could have caused an increase in serum inflammatory markers. In addition, lack of consent to participate in the study was considered as an exclusion criterion. After explaining the objectives of the study to 179 MHD patients, 122 patients consented to participate in the study. The study received an ethical approval from the ethics committee of Hasheminejad Kidney center.

The demographic data (age, gender), cause of ESKD, duration of dialysis (dialysis vintage) and monthly laboratory results were extracted from the software of our dialysis ward, i.e., Hemodialysis Data Processor Software (HDPS), AIP Company, 2014, 
Tehran. Laboratory tests included serum hemoglobin, creatinine), blood urea nitrogen, sodium, potassium, calcium, phosphorus, parathyroid hormone (iPTH), vitamin D, iron, total iron binding capacity, ferritin, lipid profile (cholesterol, triglycerides, low density lipoprotein and high density lipoprotein), albumin, uric acid, and highly sensitive C reactive protein (hsCRP). Fetuin- A was measured by using ZB-1386-H9648 kit through ELISA test.

Vascular calcification was examined though performing doppler sonography of the right and left carotid arteries. Carotid intima- media thickness (IMT) was measured at three points of the artery (upper, middle and lower) on each side and the calculated mean value was considered as IMT value. An IMT $\geq 0.8 \mathrm{~mm}$ on either side was considered as increased IMT [24]. A stenosis of more than $50 \%$, the presence of any hypoechoic or calcified plaque, or increased IMT were considered as vascular calcification. Finally, using two-dimensional echocardiography, calcification of the mitral or aortic valves and mitral annular calcification (MAC) were determined and the presence of any of these was considered as valvular calcification. The presence of any vascular and/or valvular calcification was considered as CVC. The laboratory findings were compared between the patients with and without vascular calcification, valvular calcification, and CVC and the predictors of CVC were determined.

For statistical analysis IBM SPSS Statistics for Windows, Version 22.0. Armonk, NY: IBM Corp was used. Frequency and percentage were used to describe the qualitative variables and mean and standard deviation (SD) or median (interquartile range), were used to describe the quantitative variables, where appropriate. To compare quantitative and qualitative variables between the two groups with and without calcification chi-square test and independent $t$ test or Mann-Whitney $U$ test were used, respectively. In addition, logistic regression was used to determine the predictors of CVC. P value less than 0.05 was considered as significance.

\section{Results}

Of a total of 122 patients studied, 74 patients (61\%) were male. The mean age of the patients was $58 \pm 16$ years (range: $23-87$ years). The most common cause of ESKD was diabetes observed in 56 patients (46\%), followed by unknown causes observed in 34 patients (28\%). The other causes of ESKD were hypertension, glomerulonephritis, others (polycystic kidney disease, obstructive uropathy and stone) which were observed in 15 patients (12\%), 6 patients (5\%), and 11 patients (9\%), respectively. The median (interquartile range) of dialysis vintage was 4 (3-6) years. Table 1 shows the results of laboratory tests. In 77 patients (63\%) Fetuin-A level was within normal range $(35-100 \mathrm{mg} / \mathrm{dL})$ and in 45 patients $(37 \%)$ it was lower than normal level.

Table 2 shows the results of doppler sonography of the right and left carotid arteries. Considering the stenosis of more than $50 \%$, the presence of any hypoechoic or calcified plaque or increased IMT ( $\geq 0.8 \mathrm{~mm}$ ) as vascular calcification, a total of 92 patients $(75 \%)$ had vascular calcification. Table 3 shows the results of cardiac echocardiography, which revealed valvular calcification in 89 patients $(73 \%)$. Totally 16 patients (13\%) had no calcification, 17 patients (14\%) had only vascular calcification, 14 patients (11\%) had only valvular calcification, and 75 patients (62\%) had both types of calcification. Overall 106 patients (87\%) had CVC.

Tables 4 to 6 compare the characteristics of the patients with and without vascular calcification, valvular calcification and CVC, respectively. As compared with the group without calcification, the patients with any type of calcification were older, were more affected by diabetes and had longer dialysis vintage and lower levels of serum creatinine. In addition, patients with vascular calcification also had significantly higher level of hemoglobin and lower level of serum uric acid. The patients with valvular 
calcification and CVC had also significantly lower level of calcium. There was no difference in mean Fetuin-A or the percentage of patients with reduced Fetuin-A in any type of calcification. There was also no difference between the levels of hsCRP, albumin and ferritin, assumed as indicators of inflammation, as well as serum phosphorus, iPTH, Vitamin D and lipids between the 2 groups.

In order to determine the predictors of CVC we used logistic regression analysis. Accordingly, the presence or absence of calcifications was considered as the outcome variable and the variables of age, dialysis vintage, presence or absence of diabetes, and the results of laboratory tests were considered as predictors. The predictors were entered into the model via Forward Conditional method. Table 7 shows the final predictors (Nagelkerke R Square $=0.539$ ). Increased risk of calcification was seen with a chance of 1.1 times for each year of increase in age [odds ratio (OR) $=1.1, \mathrm{CI} 95 \%=$ $1.1-1.2$ ], a chance of 2.8 times for every unit of increase in calcium $\mathrm{OOR}=2.8, \mathrm{CI} 95 \%$ $=1.1-7.6)$, and a chance of 7.4 times with existence of diabetes $(\mathrm{OR}=7.4, \mathrm{CI} 95 \%=$ 1.1 to 47.4$)$.

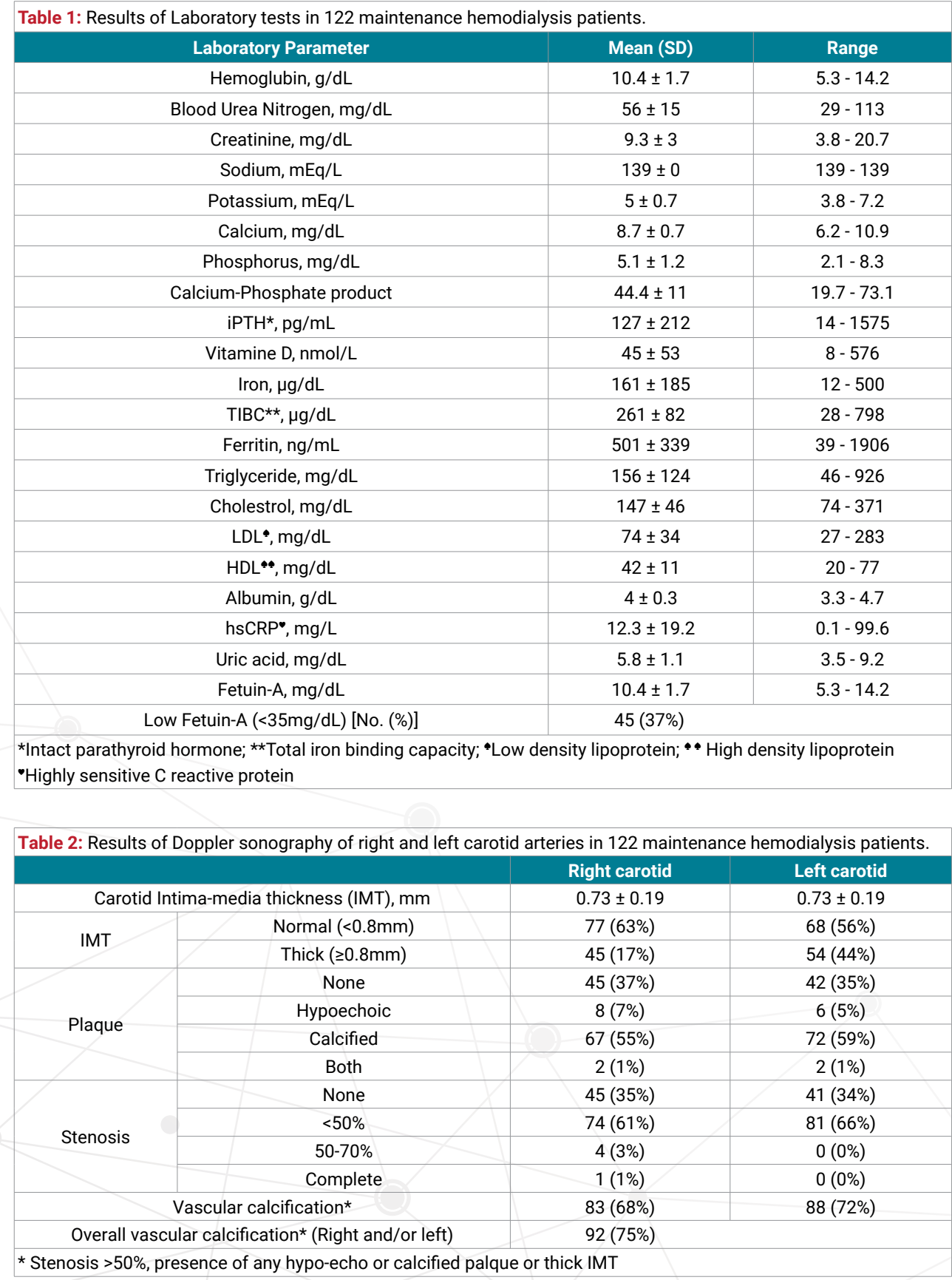


Table 3: Results of heart echocardiography in 122 maintenance hemodialysis patients.

\begin{tabular}{|c|c|c|}
\hline \multicolumn{2}{|c|}{ Mitral valve calcification } & No (\%) \\
\hline \multicolumn{2}{|c|}{ Aortic valve calcification } & $70(57 \%)$ \\
\hline \multirow{3}{*}{ Mitral annulus calcification (MAC) } & None & $66(54 \%)$ \\
\cline { 2 - 3 } & Mild & $55(45 \%)$ \\
\cline { 2 - 3 } & Moderate & $43(35 \%)$ \\
\cline { 2 - 3 } & Severe & $12(10 \%)$ \\
\hline \multirow{2}{*}{ Mitral stenosis } & None & $12(10 \%)$ \\
\cline { 2 - 3 } & Mild & $107(88 \%)$ \\
\hline \multirow{3}{*}{ Aortic stenosis } & Moderate & $10(8 \%)$ \\
\cline { 2 - 3 } & None & $5(4 \%)$ \\
\cline { 2 - 3 } & Mild & $114(93 \%)$ \\
\cline { 2 - 3 } & Moderate & $3(3 \%)$ \\
\hline \multirow{2}{*}{ Valvular calcification * } & $5(4 \%)$ \\
\hline * Mitral valve or aortic valve or any degree of MAC & $89(73 \%)$ \\
\hline
\end{tabular}

Table 4: Comparison of patients characteristics and laboratory tests in vascular calcification.

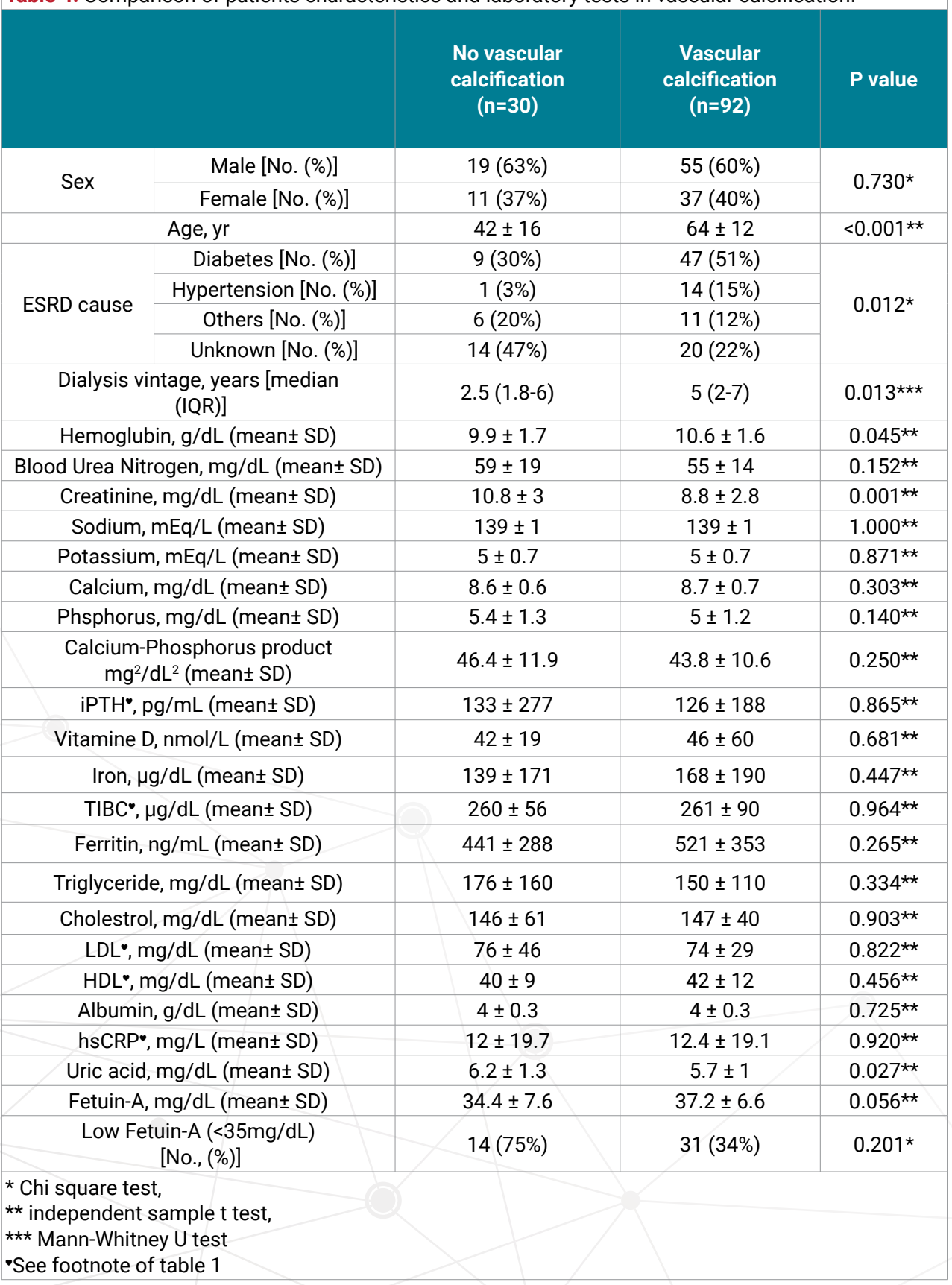




\begin{tabular}{|c|c|c|c|c|}
\hline & & $\begin{array}{l}\text { No valvular calcification } \\
(\mathrm{N}=33)\end{array}$ & $\begin{array}{l}\text { Valvular calcification } \\
\qquad(\mathrm{N}=89)\end{array}$ & $P$ value \\
\hline \multirow{2}{*}{ Sex } & Male [No. (\%)] & $22(67 \%)$ & $52(58 \%)$ & \multirow{2}{*}{$0.408^{*}$} \\
\hline & Female [No. (\%)] & $11(33 \%)$ & $37(42 \%)$ & \\
\hline \multicolumn{2}{|c|}{ Age, yr } & $47 \pm 15$ & $63 \pm 15$ & $<0.001^{\star *}$ \\
\hline \multirow{4}{*}{ ESRD cause } & Diabetes [No. (\%)] & $10(30 \%)$ & $46(52 \%)$ & \multirow{4}{*}{$0.024^{\star}$} \\
\hline & Hypertension [No. (\%)] & $2(6 \%)$ & $13(15 \%)$ & \\
\hline & Others [No. (\%)] & $6(18 \%)$ & $11(12 \%)$ & \\
\hline & Unknown [No. (\%)] & $15(46 \%)$ & $19(21 \%)$ & \\
\hline \multicolumn{2}{|c|}{ Dialysis vinytage, years [median (IQR)] } & $2(1-5)$ & $5(2-7)$ & $0.002^{\star \star *}$ \\
\hline \multicolumn{2}{|c|}{ Hemoglubin, g/dL } & $10 \pm 2$ & $10.5 \pm 1.5$ & $0.131^{\star *}$ \\
\hline \multicolumn{2}{|c|}{ Blood Urea Nitrogen, mg/dL (mean \pm SD) } & $58 \pm 17$ & $55 \pm 14$ & $0.468^{\star *}$ \\
\hline \multicolumn{2}{|c|}{ Creatinine, mg/dL (mean $\pm \mathrm{SD})$} & $10.8 \pm 3.3$ & $8.7 \pm 2.6$ & $<0.001^{\star \star}$ \\
\hline \multicolumn{2}{|c|}{ Sodium, mEq/L (mean $\pm \mathrm{SD})$} & $139 \pm 1$ & $139 \pm 1$ & $1.000^{* *}$ \\
\hline \multicolumn{2}{|c|}{ Potassium, mEq/L (mean $\pm \mathrm{SD}$ ) } & $4.9 \pm 0.7$ & $5 \pm 0.7$ & $0.562^{\star \star}$ \\
\hline \multicolumn{2}{|c|}{ Calcium, mg/dL (mean \pm SD) } & $8.4 \pm 0.7$ & $8.8 \pm 0.6$ & $0.002^{\star \star}$ \\
\hline \multicolumn{2}{|c|}{ Phsphor, mg/dL (mean \pm SD) } & $5.2 \pm 1.1$ & $5.1 \pm 1.3$ & $0.667^{\star \star}$ \\
\hline \multicolumn{2}{|c|}{$\begin{array}{l}\text { Calcium-Phosphorus product } \mathrm{mg}^{2} / \mathrm{dL}^{2} \text { (mean } \pm \\
\text { SD) }\end{array}$} & $43.6 \pm 9.9$ & $44.7 \pm 11.3$ & $0.622^{* *}$ \\
\hline \multicolumn{2}{|c|}{ iPTH, pg/mL (mean \pm SD) } & $102 \pm 76$ & $136 \pm 242$ & $0.436^{\star *}$ \\
\hline \multicolumn{2}{|c|}{ Vitamine $\mathrm{D}, \mathrm{nmol} / \mathrm{L}($ mean $\pm \mathrm{SD})$} & $58 \pm 96$ & $41 \pm 21$ & $0.111^{* *}$ \\
\hline \multicolumn{2}{|c|}{ Iron, $\mu \mathrm{g} / \mathrm{dL}$ (mean $\pm \mathrm{SD})$} & $121 \pm 152$ & $176 \pm 195$ & $0.154^{\star \star}$ \\
\hline \multicolumn{2}{|c|}{$\mathrm{TIBC}, \mu \mathrm{g} / \mathrm{dL}($ mean $\pm \mathrm{SD})$} & $261 \pm 48$ & $261 \pm 94$ & $0.995^{\star \star}$ \\
\hline \multicolumn{2}{|c|}{ Ferritin, ng/mL (mean \pm SD) } & $439 \pm 276$ & $525 \pm 358$ & $0.218^{\star \star}$ \\
\hline \multicolumn{2}{|c|}{ Triglyceride, mg/dL (mean \pm SD) } & $149 \pm 91$ & $159 \pm 134$ & $0.678^{\star \star}$ \\
\hline \multicolumn{2}{|c|}{ Cholestrol, mg/dL (mean \pm SD) } & $142 \pm 52$ & $148 \pm 44$ & $0.525^{\star \star}$ \\
\hline \multicolumn{2}{|c|}{$\mathrm{LDL}^{\bullet}, \mathrm{mg} / \mathrm{dL}($ mean $\pm \mathrm{SD})$} & $76 \pm 45$ & $74 \pm 29$ & $0.766^{\star *}$ \\
\hline \multicolumn{2}{|c|}{$\mathrm{HDL}^{*}, \mathrm{mg} / \mathrm{dL}($ mean $\pm \mathrm{SD})$} & $42 \pm 10$ & $41 \pm 12$ & $0.654^{\star \star}$ \\
\hline \multicolumn{2}{|c|}{ Albumin, $\mathrm{g} / \mathrm{dL}$ (mean $\pm \mathrm{SD})$} & $4.1 \pm 0.3$ & $4 \pm 0.3$ & $0.093^{\star \star}$ \\
\hline \multicolumn{2}{|c|}{ hsCRP", mg/L (mean \pm SD) } & $10.5 \pm 13.6$ & $12.9 \pm 20.9$ & $0.562^{\star \star}$ \\
\hline \multicolumn{2}{|c|}{ Uric acid, mg/dL (mean \pm SD) } & $6.1 \pm 1.2$ & $5.7 \pm 1$ & $0.109 \star \star$ \\
\hline \multicolumn{2}{|c|}{ Fetuin-A, mg/dL (mean $\pm S D)$} & $34.4 \pm 8.4$ & $37.3 \pm 6.1$ & $0.041^{\star \star}$ \\
\hline \multicolumn{2}{|c|}{ Low Fetuin-A (<35mg/dL) [No., (\%)] } & $15(46 \%)$ & $30(34 \%)$ & $0.232^{\star}$ \\
\hline
\end{tabular}

Table 6: Comparison of patients characteristics and laboratory tests in cardiovascular calcification.

\begin{tabular}{|c|c|c|c|c|}
\hline & & $\begin{array}{l}\text { No calcification } \\
(\mathrm{N}=16)\end{array}$ & $\begin{array}{l}\text { Calcification } \\
(\mathrm{N}=106)\end{array}$ & P value \\
\hline \multirow{2}{*}{ Sex } & Male [No. (\%)] & $10(63 \%)$ & $64(60 \%)$ & \multirow{2}{*}{$0.871^{*}$} \\
\hline & Female [No. (\%)] & $6(37 \%)$ & $42(40 \%)$ & \\
\hline \multicolumn{2}{|c|}{ Age, yr } & $38 \pm 14$ & $61 \pm 14$ & $<0.001^{\star *}$ \\
\hline \multirow{4}{*}{ ESRD cause } & Diabetes [No. (\%)] & $2(13 \%)$ & $54(51 \%)$ & \multirow{4}{*}{$0.007^{*}$} \\
\hline & Hypertension [No. (\%)] & $1(6 \%)$ & $14(13 \%)$ & \\
\hline & Others [No. (\%)] & $5(31 \%)$ & $12(1 \%)$ & \\
\hline & Unknown [No. (\%)] & $8(50 \%)$ & $26(25 \%)$ & \\
\hline \multicolumn{2}{|c|}{ Dialysis duaration, years [median(IQR)] } & $2(1-3)$ & $5(2-7)$ & $0.006^{* * *}$ \\
\hline \multicolumn{2}{|c|}{ Hemoglubin, $\mathrm{g} / \mathrm{dL}$ (mean \pm SD) } & $9.7 \pm 2.1$ & $10.5 \pm 1.6$ & $0.074^{\star \star}$ \\
\hline \multicolumn{2}{|c|}{ Blood Urea Nitrogen, $\mathrm{mg} / \mathrm{dL}$ (mean \pm SD) } & $60 \pm 19$ & $55 \pm 14$ & $0.223^{\star *}$ \\
\hline \multicolumn{2}{|c|}{ Creatinine, $\mathrm{mg} / \mathrm{dL}($ mean $\pm \mathrm{SD}$ ) } & $11.9 \pm 3.1$ & $8.9 \pm 2.8$ & $<0.001^{* *}$ \\
\hline \multicolumn{2}{|c|}{ Sodium, $\mathrm{mEq} / \mathrm{L}($ mean $\pm \mathrm{SD})$} & $139 \pm 1$ & $139 \pm 1$ & $1.000^{\star *}$ \\
\hline \multicolumn{2}{|c|}{ Potassium, $\mathrm{mEq} / \mathrm{L}($ mean $\pm \mathrm{SD})$} & $4.9 \pm 0.8$ & $5 \pm 0.7$ & $0.716^{\star \star}$ \\
\hline \multicolumn{2}{|c|}{ Calcium, $\mathrm{mg} / \mathrm{dL}($ mean $\pm \mathrm{SD})$} & $8.4 \pm 0.5$ & $8.7 \pm 0.7$ & $0.026^{\star *}$ \\
\hline \multicolumn{2}{|c|}{ Phsphorus, mg/dL (mean \pm SD) } & $5.2 \pm 0.9$ & $5.1 \pm 1.3$ & $0.826^{\star \star}$ \\
\hline \multicolumn{2}{|c|}{ Calcium-Phosphorus product $\mathrm{mg}^{2} / \mathrm{dL}^{2}($ mean $\pm \mathrm{SD})$} & $43.3 \pm 8.6$ & $44.6 \pm 11.3$ & $0.671^{\star *}$ \\
\hline \multicolumn{2}{|c|}{ iPTH,pg/mL (mean \pm SD) } & $84 \pm 52$ & $134 \pm 227$ & $0.382^{\star \star}$ \\
\hline \multicolumn{2}{|c|}{ Vitamine $\mathrm{D}, \mathrm{nmol} / \mathrm{L}($ mean $\pm \mathrm{SD}$ ) } & $47 \pm 20$ & $45 \pm 56$ & $0.902^{\star \star}$ \\
\hline \multicolumn{2}{|c|}{ Iron, $\mu \mathrm{g} / \mathrm{dL}($ mean $\pm \mathrm{SD})$} & $142 \pm 179$ & $164 \pm 187$ & $0.657^{\star *}$ \\
\hline \multicolumn{2}{|c|}{ TIBC", $\mu \mathrm{g} / \mathrm{dL}($ mean $\pm \mathrm{SD})$} & $255 \pm 40$ & $262 \pm 87$ & $0.775^{\star \star}$ \\
\hline \multicolumn{2}{|c|}{ Ferritin, $\mathrm{ng} / \mathrm{mL}$ (mean $\pm \mathrm{SD})$} & $395 \pm 294$ & $518 \pm 343$ & $0.178^{\star \star}$ \\
\hline \multicolumn{2}{|c|}{ Triglyceride, $\mathrm{mg} / \mathrm{dL}$ (mean $\pm \mathrm{SD}$ ) } & $138 \pm 81$ & $159 \pm 129$ & $0.534^{\star \star}$ \\
\hline \multicolumn{2}{|c|}{ Cholestrol, $\mathrm{mg} / \mathrm{dL}($ mean $\pm \mathrm{SD}$ ) } & $140 \pm 68$ & $148 \pm 42$ & $0.529^{* *}$ \\
\hline \multicolumn{2}{|c|}{$\mathrm{LDL}^{\bullet}, \mathrm{mg} / \mathrm{dL}($ mean $\pm \mathrm{SD})$} & $82 \pm 58$ & $73 \pm 29$ & $0.327^{\star *}$ \\
\hline \multicolumn{2}{|c|}{$\mathrm{HDL}, \mathrm{mg} / \mathrm{dL}($ mean $\pm \mathrm{SD})$} & $39 \pm 7$ & $42 \pm 12$ & $0.381^{\star *}$ \\
\hline \multicolumn{2}{|c|}{ Albumin, $\mathrm{g} / \mathrm{dL}($ mean $\pm \mathrm{SD})$} & $4 \pm 0.2$ & $4 \pm 0.3$ & $0.747^{\star \star}$ \\
\hline \multicolumn{2}{|c|}{ hsCRP”, mg/L (mean \pm SD) } & $7.6 \pm 9$ & $13.1 \pm 20.3$ & $0.296^{\star *}$ \\
\hline \multicolumn{2}{|c|}{ Uric acid, mg/dL (mean $\pm \mathrm{SD}$ ) } & $6.3 \pm 1.4$ & $5.7 \pm 1$ & $0.086^{\star *}$ \\
\hline \multicolumn{2}{|c|}{ Fetuin- $\mathrm{A}, \mathrm{mg} / \mathrm{dL}$ (mean $\pm \mathrm{SD}$ ) } & $33.9 \pm 9.2$ & $36.9 \pm 6.4$ & $0.101^{\star *}$ \\
\hline \multicolumn{2}{|c|}{ Low Fetuin-A (<35mg/dL) [No., (\%)] } & $6(37 \%)$ & $39(37 \%)$ & $0.956^{*}$ \\
\hline
\end{tabular}




\begin{tabular}{|c|c|c|c|c|c|c|c|c|}
\hline & \multirow{2}{*}{ B } & \multirow{2}{*}{ S.E. } & \multirow{2}{*}{ Wald } & \multirow{2}{*}{ df } & \multirow{2}{*}{ Sig. } & \multirow{2}{*}{$\operatorname{Exp}(B)$} & \multicolumn{2}{|c|}{ 95\% C.I. for EXP(B) } \\
\hline & & & & & & & Lower & Upper \\
\hline Age & .111 & .027 & 17.097 & 1 & $<0.001$ & 1.117 & 1.060 & 1.178 \\
\hline Serum Calcium & 1.045 & .503 & 4.321 & 1 & 0.038 & 2.844 & 1.062 & 7.621 \\
\hline Diabetes mellitus & 1.999 & .949 & 4.438 & 1 & 0.035 & 7.385 & 1.149 & 47.447 \\
\hline Constant & -13.084 & 4.654 & 7.904 & 1 & 0.005 & .000 & & \\
\hline
\end{tabular}

\section{Discussion}

According to the findings of this study, $87 \%$ of our MHD patients had either vascular or valvular, i.e. cardiovascular calcification. Comparison of different characteristics between patients with and without calcifications showed that patients with calcification were more likely to be older, have longer dialysis vintage, and have diabetes mellitus. They also had lower serum creatinine and higher calcium levels. However, there was no significant in Fetuin-A level between the patients with or without calcification. The results of logistic regression analysis showed that age, serum calcium level, and diabetes mellitus were the most important predictors of calcification in these patients.

Calcification of the aortic and mitral valves is a common finding in MHD patients with a prevalence of four to five times higher than that in the general population [2526]. In the study by Ribeiro et al., the prevalence of mitral and aortic calcification were $44.5 \%$ and $52 \%$ in patients with CKD-5D, and were higher than those with normal renal function ( $10 \%$ and $4.3 \%$, respectively) [26]. Raggi et al. reported a prevalence of $45 \%$ and $34 \%$, for mitral and aortic valve calcifications in patients with ESRD, as detected by CT scan. In addition, the prevalence of simultaneous involvement of both valves was $21 \%$ [25]. In the study by Rao et al, the prevalence of MAC in dialysis patients was 35\% [27]. Sayarlioglu et al. studied 129 hemodialysis patients and their results showed a $23.3 \%$ prevalence of mitral valve calcification, a $21.7 \%$ prevalence of aortic valve calcification and the overall $33.3 \%$ prevalence of valvular abnormalities was [28]. In our study, the prevalence of mitral calcification, aortic calcification, and MAC, were $57 \%, 54 \%$, and $55 \%$ respectively, and the overall valvular calcification was $73 \%$, which is higher than the rates reported by other studies. This higher prevalence might be attributed to several factors such as differences in the study populations, especially regarding mean age and dialysis vintage, different definitions and diagnostic methods for detection of CVC, the type of phosphate binders used and dialysate calcium concentration. We have been using Calcium carbonate as the main phosphate binder in the country till about 6 years ago, when sevelamer was covered by insurance companies and this could have been an explanation for high rate of vascular calcification. On the other hand, the concentration of dialysate calcium is low at $2.5 \mathrm{mmol} / \mathrm{L}$ in our country and may be beneficial regarding causing less calcification. Further studies on cumulative doses of calcium- based vs. non- calcium- based phosphate binders may help to determine the effect of oral calcium supplements and phosphate binders on vascular calcification.

According to previous studies, dialysis patients with vascular calcification are older and have longer duration of dialysis [29-30]. Our study also confirmed that patients with any type of calcification were older and had a longer dialysis vintage, though dialysis vintage lost its effect in our regression analysis. These findings suggests that age, as a major atherosclerotic risk factor plays an important role in calcification of dialysis patients and also longer exposure to the uremic milieu has a detrimental role in provocation of vascular calcification.

Factors such as diabetes mellitus, disorders of metabolism of calcium and phosphorus including high serum calcium level, high calcium-phosphate product, and inflammation have been introduced as important predictors of CVC in these patients [26,28,31-34]. In our study hsCRP, ferritin and (low) albumin, assumed as 
markers of inflammation, had no correlation with vascular calcification. It is possible that more specific markers of inflammation such as pre-albumin and Il6 would have shown the correlation between vascular calcification and inflammation. On the other hand, higher levels of calcium was a predictor of $\mathrm{CV}$ in both univariate and logistic regression analysis. Other studies have mentioned the relationship between high calcium intake, high calcium- phosphorus product or high serum calcium levels with vascular calcification in MHD patients $(31,33,35,36)$.

Although there is some evidence indicating an association between low levels of Fetuin-A and coronary artery calcification, the incidence of cardiovascular events, and mortality, not all studies prove such an association [37-39]. Hermans et al. reported that Fetuin-A does not act as an independent predictor of vascular stiffness in dialysis patients, after adjusting for age, gender, mean arterial pressure and diabetes mellitus [16]. Also Jung et al. showed that, the inverse relationship between Fetuin-A and coronary artery calcification is lost after adjusting for age [40]. Moreover, Pencak et al. did not find any significant difference in Fetuin-A level and between hemodialysis patients and healthy subjects, despite the apparent difference in coronary artery calcification score between the two groups [41].

There are a limited number of studies on the relationship between Fetuin-A and carotid IMT or valvular calcification. However, as mentioned in coronary artery calcification, the findings are controversial. Odamaki et al. reported an inverse relationship between Fetuin-A and carotid IMT [21]. Caglar et al. reported the same inverse relationship in non-diabetic patients with CKD stages 1 to 5 ; however, they did not observe this relationship in the multivariate analysis [42]. Schlieper et al. found no relationship between Fetuin-A and IMT in hemodialysis patients and Hermans et al. also noted that the relationship between Fetuin-A disappears after adjusting for age [43]. According to Ziolkowska et al., low level of Fetuin-A in children and adults with ESKD is an independent predictor of higher carotid IMT; however, this was not true for patients with CKD stages 2-4 [44]. In the study by Pertosa et al, the baseline level of Fetuin-A was inversely and independently associated with carotid IMT measured two years later [45]. Moreover, Pateinakis et al. reported an inverse relationship in 81 chronic hemodialysis patients; however, the observed relationship disappeared after adjusting for age [46].

There are also controversial findings and reports on the relationship between Fetuin-A level and the valvular calcification in hemodialysis patients. Hermans et al failed to prove the role of Fetuin-A as an independent risk factor for aortic stiffness [16]. Lee et al. reported that the Fetuin-A level was lower in patients with valvular calcification [37]. However, Mann et al. who conducted a study on patients with ESKD in India failed to find a relationship between Fetuin-A and aortic calcification [47].

Considering the controversial results of the studies on the relationship between Fetuin-A level and valvular or vascular calcification in hemodialysis patients, results of our study, which showed no significant relationship between CVC and Fetuin-A level, are not much unexpected. The differences in methodology and study populations with different characteristics can partially explain the observed controversies and differences. It has also been stated that serum Fetuin-A in CKD patients is more observed as Fetuin-mineral complex (FMC), and not as free Fetuin-A [48]. FMC is a combination of Fetuin-A, fibrinogen, fibronectin 1 , and calcium. In fact, with reducing GFR level, the FMC level, and not the level of free Fetuin-A, increases. This is associated with higher levels of coronary artery calcification score in dialysis patients [48]. So it seems that, based on the current knowledge, circulating serum Fetuin-A has a poor relationship with CVC [49]. In addition, some other factors such as obesity, insulin resistance, metabolic syndrome, nonalcoholic fatty liver, lifestyle, smoking, adynamic bone diseases, and the use of vitamin D metabolites can affect the Fetuin-A level [50]. Moreover, the presence of different coding genes of Fetuin-A can affect its level in different populations [51]. 


\section{Conclusion}

The findings of our study showed that a high percentage of patients undergoing chronic hemodialysis (87\%) had vascular or valvular calcification and age, calcium level, and diabetes were identified as the most important predictors of calcification in these patients. The Fetuin-A level was not different between patients with and without CVC and was not recognized as a predictor.

It is recommended to conduct longitudinal studies to examine the evolution of CVC and its' risk factors over time and to study the level of Fetuin-mineral complex, which may be a better representative of Fetuin effect on soft tissues.

\section{References}

1. Collins AJ, Foley RN, Herzog C, Chavers BM, Gilbertson D, et al. Excerpts From the US Renal Data System 2009 Annual Data Report. Am J Kidney Dis. 2010; 55: A6-A7. Ref.: https://goo.gl/s3HHAZ

2. Efstratiadis G, Koskinas $\mathrm{K}$, Pagourelias $\mathrm{E}$. Coronary calcification in patients with end-stage renal disease: a novel endocrine disorder? Hormones (Athens). 2007; 6: 120-131. Ref.: https://goo.gl/grJQZZ

3. Tomiyama C, Higa A, Dalboni MA, Cendoroglo M, Draibe SA, et al. The impact of traditional and nontraditional risk factors on coronary calcification in pre-dialysis patients. Nephrol Dial Transplant. 2006; 21: 2464-2471. Ref.: https://goo.gl/wFiQwJ

4. Muntner $\mathrm{P}, \mathrm{He} \mathrm{J}$, Astor $\mathrm{BC}$, Folsom AR, Coresh J. Traditional and nontraditional risk factors predict coronary heart disease in chronic kidney disease: results from the atherosclerosis risk in communities study. J Am Soc Nephrol. 2005; 16: 529-538. Ref.: https://goo.gl/TvkUea

5. Nitta K. Vascular calcification in patients with chronic kidney disease. Therapeutic Apheresis and Dialysis. 2011; 15: 513-521. Ref.: https://goo.gl/A4BtKv

6. Shroff RC, Shanahan CM. The vascular biology of calcification. In, Seminars in dialysis: Wiley Online Library. 2007; 103-109. Ref.: https://goo.gl/Y3pWyw

7. Braun J, Oldendorf $M$, Moshage $W$, Heidler R, Zeitler E, et al. Electron beam computed tomography in the evaluation of cardiac calcifications in chronic dialysis patients. Am J Kidney Dis. 1996; 27: 394401. Ref.: https://goo.gl/wivqVu

8. Mizobuchi M, Towler D, Slatopolsky E. Vascular calcification: the killer of patients with chronic kidney disease. J Am Soc Nephrol. 2009; 20: 1453-1464. Ref.: https://goo.gl/H6e9WD

9. Giachelli CM, Speer MY, Li X, Rajachar RM, Yang H. Regulation of vascular calcification roles of phosphate and osteopontin. Circ Res. 2005; 96: 717-722. Ref.: https://goo.gl/qBocwq

10. Ossareh S. Vascular calcification in chronic kidney disease: mechanisms and clinical implications. Iran J Kidney Dis. 2011; 5: 285-299. Ref.: https://goo.gl/r4F15a

11. Reynolds JL, Skepper JN, McNair R, Kasama T, Gupta K, et al. Multifunctional Roles for Serum Protein Fetuin-A in Inhibition of Human Vascular Smooth Muscle Cell Calcification. J Am Soc Nephrol. 2005. 16: 2920-2930. Ref.: https://goo.gl/vU2GmJ

12. Oikawa O, Higuchi T, Yamazaki T, Yamamoto C, Fukuda N, Matsumoto K. Evaluation of serum fetuin-A relationships with biochemical parameters in patients on hemodialysis. Clin Exp Nephrol. 2007; 11: 304-308. Ref.: https://goo.gl/pM12u8

13. Imel EA, Econs MJ. Fibroblast growth factor 23: roles in health and disease. J Am Soc Nephrol. 2005; 16: 2565-2575. Ref.: https://goo.gl/NB8aFC

14. Stenvinkel P, Wang K, Qureshi AR, Axelsson J, Pecoits-Filho R, et al. Low fetuin-A levels are associated with cardiovascular death: impact of variations in the gene encoding fetuin. Kidney Int. 2005; 67: 2383-2392. Ref.: https://goo.gl/2TZDFs

15. Wang AYM, Woo J, Lam CWK, Wang M, Chan IHS, et al. Associations of serum fetuin-A with malnutrition, inflammation, atherosclerosis and valvular calcification syndrome and outcome in peritoneal dialysis patients. Nephrol Dial Transplant. 2005; 20: 1676-1685. Ref.: https://goo.gl/1KBGce

16. Hermans MM, Brandenburg V, Ketteler M, Kooman JP, van der Sande FM, et al. Study on the relationship of serum fetuin-A concentration with aortic stiffness in patients on dialysis. Nephrol Dial Transplant 2006; 21: 1293-1299. Ref.: https://goo.gl/ZUXaZm 
17. Jung HH, Kim S-W, Han $\mathrm{H}$. Inflammation, mineral metabolism and progressive coronary artery calcification in patients on haemodialysis. Nephrol Dial Transplant. 2006; 21: 1915-920. Ref.: https://goo.gl/piqZ9L

18. Mehrotra R, Westenfeld R, Christenson $P$, Budoff $M$, Ipp E, et al. Serum fetuin-A in nondialyzed patients with diabetic nephropathy: relationship with coronary artery calcification. Kidney Int. 2005; 67: 1070-1077. Ref.: https://goo.gl/9StwKn

19. Ketteler $M$, Wanner $C$, Metzger $T$, Bongartz $P$, Westenfeld $R$, et al. Deficiencies of calcium-regulatory proteins in dialysis patients: a novel concept of cardiovascular calcification in uremia. Kidney Int. 2003; 63: S84-S87. Ref.: https://goo.gl/BWBeuc

20. Moe SM, Reslerova M, Ketteler M, O'Neill K, Duan D, et al. Role of calcification inhibitors in the pathogenesis of vascular calcification in chronic kidney disease (CKD). Kidney Int. 2005; 67: 22952304. Ref.: https://goo.gl/Tpbca8

21. Odamaki M, Shibata $T$, Takita $T$, Kumagai $H$. Serum fetuin-A and aortic calcification in hemodialysis patients. Kidney Int 2005; 68: 2915. Ref.: https://goo.gl/vKSPSF

22. Ossareh $S$, Alaei A, Saedi D. Carotid intima-media thickness in maintenance hemodialysis patients: role of cardiovascular risk factor. Iran J Kidney Dis. 2011; 5: 169. Ref.: https://goo.gl/X2tzGM

23. El-Shehaby AM, Zakaria A, El-Khatib M, Mostafa N. Association of fetuin-A and cardiac calcification and inflammation levels in hemodialysis patients. Scand J Clin Lab Invest. 2010; 70: 575-582. Ref.: https://goo.gl/EgRj3A

24. Paul J, Shaw K, Dasgupta S, Ghosh MK. Measurement of intima media thichness of carotid artery by B-mode ultrasound in healthy people of India and Bangladesh, and relation of age and sex with carotid artery intima media thickness: : An observational study. J Cardiovasc Dis Res. 2012; 3: 128131. Ref.: https://goo.gl/kxGNZ2

25. Raggi P, Boulay A, Chasan-Taber S, Amin N, Dillon M, et al. Cardiac calcification in adult hemodialysis patients: A link between end-stage renal disease and cardiovascular disease? J Am Coll Cardiol. 2002; 39: 695-701. Ref.:

26. Ribeiro S, Ramos A, Brandao A, Rebelo JR, Guerra A, Resina C, et al. Cardiac valve calcification in haemodialysis patients: role of calcium-phosphate metabolism. Nephrol Dial Transplant. 1998; 13 : 2037-2040. Ref.: https://goo.gl/4cYR5a

27. Rao AK, Djamali A, Korcarz CE, Aeschlimann SE, Wolff MR, et al. Mitral annular calcification is associated with reduced left ventricular function and inflammation in patients with chronic kidney disease. J Am Soc Echocardiogr. 2008; 2: 747-750. Ref.: https://goo.gl/NuLvWP

28. Sayarlioglu H, Acar G, Sahin M, Altunoren O, Yavuz YC, et al. Prevalence and risk factors of valvular calcification in hemodialysis patients. Iran J Kidney Dis. 2013; 7: 129-134. Ref.: https://goo.gl/hTxQVP

29. Mazzaferro S, Coen G, Bandini S, Borgatti $P$, Ciaccheri $M$, et al. Role of ageing, chronic renal failure and dialysis in the calcification of mitral annulus. Nephrol Dial Transplant. 1993; 8: 335-340. Ref.: https://goo.gl/UGXUvR

30. Raggi P, Bellasi A, Gamboa C, Ferramosca E, Ratti C, et al. All-cause mortality in hemodialysis patients with heart valve calcification. Clinical J Am Soc Nephrol. 2011; 6: 1990-1995. Ref.: https://goo.gl/NXHvCy

31. Wang $\mathrm{C}$, Jiang L, Feng S, Shi Y, Shen $\mathrm{H}$, et al. Risk factor analysis of calcification in aortic and mitral valves in maintenance peritoneal dialysis patients. Kidney and Blood Pressure Research. 2013; 37: 488-4895. Ref.: https://goo.gl/S8Wz5y

32. Nemcsik J, Kiss I, Tislér A. Arterial stiffness, vascular calcification and bone metabolism in chronic kidney disease. World J Nephrol. 2012; 1: 25-34. Ref.: https://goo.gl/3gQzyD

33. Tarrass F, Benjelloun M, Zamd M, Medkouri G, Hachim K, et al. Heart valve calcifications in patients with end-stage renal disease: Analysis for risk factors. Nephrology. 2006; 11: 494-496. Ref.: https://goo.gl/6M6tBq

34. Wang AYM, Ho SSY, Wang M, Liu EKH, Ho S, et al. Cardiac valvular calcification as a marker of atherosclerosis and arterial calcification in end-stage renal disease. Arch Intern Med. 2005; 165: 327-332. Ref.: https://goo.gl/e9wJ6S

35. London GM, Marchais SJ, Guérin AP, Métivier F. Arteriosclerosis, vascular calcifications and cardiovascular disease in uremia. Curr Opin Nephrol Hypertens. 2005; 14: 525-531. Ref.: https://goo.gl/Pc64vj

36. Moe SM, Chen NX. Pathophysiology of vascular calcification in chronic kidney disease. Circ Res. 2004; 95: 560-567. Ref.: https://goo.gl/nXJTWn 
37. Lee CT, Chua S, Hsu CY, Tsai YC, Ng HY, et al. Biomarkers Associated with Vascular and Valvular Calcification in Chronic Hemodialysis Patients. Dis Markers. 2013; 34: 229-235. Ref.: https://goo.gl/xBfk3d

38. Abdel-Wahab AF, Fathy O, Al-Harizy R. Negative correlation between fetuin-A and indices of vascular disease in systemic lupus erythematosus patients with and without lupus nephritis. Arab J Nephrol Transplant. 2013; 6: 11-20. Ref.: https://goo.gl/WQZuGM

39. Jung JY, Hwang YH, Lee SW, Lee H, Kim DK, et al. Factors associated with aortic stiffness and its change over time in peritoneal dialysis patients. Nephrol Dial Transplant. 2010; 25: 4041-4048. Ref.: https://goo.gl/wQE9Ub

40. Jung HH, Baek HJ, Kim SW. Fetuin-A, coronary artery calcification and outcome in maintenance hemodialysis patients. Clin Nephrol. 2011; 75: 391-396. Ref.: https://goo.gl/TxvHe4

41. Pencak P, Czerwieńska B, Ficek R, Wyskida K, Kujawa-Szewieczek A, et al. Calcification of coronary arteries and abdominal aorta in relation to traditional and novel risk factors of atherosclerosis in hemodialysis patients. BMC Nephrol 2013; 14: 10. Ref.: https://goo.gl/ujA4Yj

42. Caglar K, Yilmaz MI, Saglam M, Cakir E, Kilic S, et al. Serum fetuin-a concentration and endothelial dysfunction in chronic kidney disease. Nephron Clin Pract. 2008; 108: c233-c240. Ref.: https://goo.gl/cZnpQn

43. Hermans $\mathrm{MMH}$, Kooman JP, Brandenburg V, Ketteler M, Damoiseaux JGMC, et al. Spatial inhomogeneity of common carotid artery intima-media is increased in dialysis patients. Nephrol Dial Transplant. 2007; 22: 1205-1212. Ref.: https://goo.gl/rMm6LY

44. Ziolkowska $\mathrm{H}$, Brzewski M, Roszkowska-Blaim M. Determinants of the intima-media thickness in children and adolescents with chronic kidney disease. Pediatr Nephrol. 2008; 23: 805-811. Ref.: https://goo.gl/bA7NeE

45. Pertosa G, Simone S, Ciccone M, Porreca S, Zaza G, et al. Serum Fetuin A in Hemodialysis: A Link Between Derangement of Calcium-Phosphorus Homeostasis and Progression of Atherosclerosis? Am J Kidney Dis. 2009; 53: 467-474. Ref.: https://goo.gl/H3vWmF

46. Pateinakis $P$, Papagianni A, Douma S, Efstratiadis G, Memmos D. Associations of fetuin-A and osteoprotegerin with arterial stiffness and early atherosclerosis in chronic hemodialysis patients. BMC Nephrology. 2013; 14: 122. Ref.: https://goo.gl/nBQC6S

47. Mann A, Makkar V, Mann S, Dhamija P, Soundarajan P. Fetuin-A and vascular calcification in Indian end-stage renal disease population. Indian J Nephrol. 2016; 26: 33-38. Ref.: https://goo.gl/ABCFKn

48. Hamano T, Matsui I, Mikami S, Tomida K, Fujii N, Imai E, et al. Fetuin-mineral complex reflects extraosseous calcification stress in CKD. J Am Soc Nephrol. 2010; 21: 1998-2007. Ref.: https://goo.gl/Ds2bTp

49. Liabeuf S, Okazaki H, Desjardins L, Fliser D, Goldsmith D, Covic A, et al. Vascular calcification in chronic kidney disease: are biomarkers useful for probing the pathobiology and the health risks of this process in the clinical scenario? Nephrol Dial Transplant. 2014; 29: 1275-1284. Ref.: https://goo.gl/DfozG2

50. Brix JM, Stingl H, Höllerl F, Schernthaner GH, Kopp HP, et al. Elevated Fetuin-A concentrations in morbid obesity decrease after dramatic weight loss. J Clin Endocrinol Metab. 2010; 95: 4877-4881. Ref.: https://goo.gl/HkqXKP

51. Ghorbanihaghjo A, Argani H, Samadi N, Valizadeh S, Halajzadeh J, et al. Relationship Between Vitamin D Receptor Gene Fokl and Apal Polymorphisms and Serum Levels of Fetuin-A, Vitamin D, and Parathyroid Hormone in Patients on Hemodialysis. Iran J Kidney Dis. 2014; 8: 394-400. Ref.: https://goo.gl/pxgrxw 